\title{
The Impact of the Animated Children's Program of Baby TV on the Handled Government-Language Development of the Child
}

\author{
Müller Mirella ${ }^{1, *} \&$ Johann Schwarz, Logopäd ${ }^{2}$ \\ ${ }^{1}$ Department of Pedagogy, Faculty of Humanities and Social Sciences, University of Osijek, Croatia \\ ${ }^{2}$ Medizinisches Fakulät Mannheim, Theodor-Kutzer-Ufer, 68167-Mannheim, Haus 24 - Ebene 4, Germany \\ *Correspondence: Department of Pedagogy, Faculty of Humanities and Social Sciences, University of Osijek, \\ Croatia. Tel: 385-998-327-771. E-mail: mtolic@ffos.hr
}

Received: May 13, 2019

Accepted: June 18, 2019 Online Published: June 24, 2019

doi:10.5430/wje.v9n3p118

URL: https://doi.org/10.5430/wje.v9n3p118

\begin{abstract}
Speech disorders are in almost all speech pathology accompanied by a symptom. They usually occur during speech development. Baby. First TV describes itself as a provider of shows 'designed to inspire a baby's learning'. However, if a child is presented to a continental strangling program that does not serve the mother tongue, it can have a lot of difficulty in shaping the language of her speech and not understanding the words and sentences of her parents and the environment. The subjects in this study carried out the following diagnostic tests: pedagogical-psychological examination, logaoedic examination, and neurological examination. The results research shows that besides the worse results on non-verbal intelligence tests, children who were exposed to the influence of Baby-TV from their 2 to 4-year-olds have achieved worse results on nonverbal tests as well as children whose parents included the Baby-TV program of 9 months to the gosling of the day. They say the worst German letters such as $B, R, \ddot{O}, \ddot{A}, \ddot{U}$ and do not associate German spoken words with the environment. The aim of this research was to examine the negative influence of BABY TV on the speech of children with age child, sex, nonverbal, verbal abilities, and development scale of understanding speech. The ability to speak and understand speech in relation to Reynell was also explored development scale of speech. Average and below-average values were obtained.
\end{abstract}

Keywords: language-speaking difficulties, rehabilitation, the influence of an animated children's program, parents, education

\section{Introduction}

Media education should include the experience, the culture of communication that leads back to the man and the possibilities of action. On the one hand, should be taken of the current life situations, needs, and preferences of young people, and on the other hand, it is necessary to monitor the cognitive development and expand the knowledge of children and young people in the use and analysis of the media. Every eighth child has a speech disorder. On this number comes an extrapolation of the health insurance Barmer GEK. This is not just medical causes. Pediatricians attribute the development also to failures in the home. Pediatricians diagnosed language development disorders in 2015 with 715,000 statutory boys and girls. That was twelve percent. In comparison, in 2011, there were 648,000 children and adolescents between the ages of five and 14, which corresponds to 9.8 percent. According to the report, boys are more frequently affected (14.4\%) than girls $(9.4 \%)$ (note 1$)$. However, there are hardly any regional differences. More children are sent to the speech therapist. A study by another large health insurance fund confirms the trend: According to an analysis of the AOK, the prescription of speech therapy for children has increased by a quarter in the past ten years. In the meantime, every fourth six-year-old boy receives such support, according to the AOK's Scientific Institute (WIdO) in the 2016 Remedy Report(note 2). Social causes are more common than medical ones. The Professional Association of Pediatricians has been observing for years that language deficits are increasing. "But we have to distinguish between medical and social causes," said spokesman Hermann Josef Kahl(note 3). For medical reasons, it concerns, for example, lisp, Lallen or even hearing problems or mental disabilities (Adomeit, 1997). The following educational principles serve as guidelines for the development of media education: First, The orientation of the situation: the starting point for the media and the educational process should be the situation of the living space's children and young people (not to impose, but to propose). Second, orientation communication: media education 
should be designed in a communicative way and lead to the expansion of opportunities of personal and media communication. Third, the orientation of needs: the needs of children and young people who are associated with the use of the media (to protect children using the media, but to offer another activity). Fourth, orientation experience: children and young people should have the opportunity to introduce my experiences in the educational process. Fifth, orientation development: media education should follow the cognitive development of children and young people and support their overall future development. From the above principles goal is to get to know and evaluate media content, and parents must play a key role. Assuming that the media emotionally affecting children and young people in this area of the task is about the feelings, which are run media, knowledge, and practice in the field of personal relationships. Children and young people then learn different basic categories of media creation and mediation, for example. Distinction information and entertainment or reports and opinions. They need to learn how to create and disseminate their messages by using the media and know how to develop a culture of communication, not only in the family but also in the school curriculum. For example may make newspapers, films, radio plays, and computer programs. They thereby take on the role of creators of media content rather than the role of consumers.

\section{Area Descriptions}

Digital society implies a transformation of the traditional way of life and the economic, industrial, educational, and labor changes as well as changes of personal and individual way of existence, but also the question of the "new" partnership in education (Kolonko, 2002). The need for technological skills and knowledge in the school, in the workplace, and generally in all social activities are a consequence of living in a digital environment for which Alvin Toftler coined the term "Information Age" (Farke, 2006). For the teachers to respond to the increasingly numerous and demanding needs of digital or information society, they need to have certain knowledge, skills, and abilities which can help them with the easier implementation of teaching content. Under the flurry of globalization, particularly with the appearance of new media, the behavior and motivation in learning are significantly changing. The imperative of contemporary society and schools, with expertise in the professional domains, is certainly creativity, innovation, critical and reflective attitude, metacognitive skills, and motivation to acquire knowledge and skills (Rychen \& Salganik, 2000; Farke, 2006). Since the development of books, radio, television, and electronic media, there is a great discussion by experts how the media contribute to the development of motivation in learning, especially learning certain teaching units in the field of mathematics. There is a constant strive to invest in schools and the education system, so there are always new educational and teaching technologies in the schools (Ashauer, 2004). Accordingly, a pedagogical problem is how to install the computer in the teaching process, as well as how to use computers to assist the teaching process to make it more efficient and more interesting. BabyFirstTV describes itself as a provider of shows 'designed to inspire a baby's learning'. The service, which lets children interact, does not feature any commercials and advises parents against long periods of viewing. BabyTV also airs in the UK and France. It is designed to provide a 'safe, stimulating and educational environment' for toddlers. Similar internet services like this have also been launched in recent years. A report by Official Journal of the American Academy of Pediatrics in 2007 found watching entertainment TV before the age of three caused attention problems. Claude Knights, director of children's charity Kidscape, has called on Ofcom to make parents more aware of the dangers. He said: 'It is really sad when TV is used as a babysitter or a means of controlling very young children. 'There may well be parents that don't realize the cumulative effects of exposure to TV. Ofcom should state the case and give the concerns about possible harm revealed in this research.' Ofcom said: 'The CSA has made Ofcom aware of its concerns regarding TV programming aimed at very young children. 'Ofcom takes the protection of minors extremely seriously and notes that BabyFirstTV provides information to parents about how best to allow their children to interact with its programming and advises against long periods of viewing for young children. 'At present, there has been no evidence supplied to Ofcom that proves such content is harmful to minors. 'However, Ofcom has asked the CSA for any research which supports their concerns and will consider in detail any research it can provide.' An audience of under-3s: Two dedicated baby channels have been launched on British television in recent years. BabyFirstTV appeared on Sky in 2007 and BabyTV began on cable in October 2005(note 4). Both air 24 hours a day and are aimed at children aged three and under. Rupert Murdoch's News Corporation owns BabyTV, which broadcasts in more than 70 countries. BabyFirstTV is a US-based enterprise backed by an Israeli/Dutch group(note 5). It also broadcasts in a number of languages and countries. Both channels claim to work with experts in the field of child development in the programming they make. Typical output includes puppet shows and rhymes for bedtime; in particular, it raises the question of how the Beby TV program influences the development of the speech of the child or the development of language competitor(note 6). Language is a natural communication system. Speech is the language in action, optimal audio communication. The first three years of life are the most intense for linguistic-speech development of the child. Communication of the child 
with the environment begins already in the mother's womb the child can hear the sound stimulus and respond by moving. The first child's vocal communication cry is after birth. Pre-school child, mastering speech, pass through two phases - the prediction and the linguistic phase. "The linguistic agreement, in its oral or written form, the most common and most complete way of understanding among people "(Pavličević-Franic, 2005: 21). Properly dosed and carefully selected TV shows and cartoons they can also enhance the child's language-language development and contribute to the adoption of new knowledge. In selecting a television program and setting the time that children can spend on the screen, parents have a crucial role to play(note 7), they will with a thoughtful approach to helping your children create healthy television habits. "Kids surrounded by words almost always talk completely before three years have passed. The kids she talks a bit, I can have (Silberg, 2006: 39). Earlier introduction of music in the game also increases children's language acquisition options. Today there are exist games that encourage and develop the child's speech abilities before you say your first word, the child needs to master the skilled voice and song pronunciation. It is used to imitate, but it is of great importance and stimulates the environment (Gerhard \& Streit, 2002). About the first year of life, the child is ready to pronounce first words. In a stimulating environment, it is easier to adopt new words. The child plays it must never be compelled, but entertainment and fun. Every game must be played adapt to the reception capabilities and each child's game needs to be followed by a child mood, for example the songs like Deutsche Spieluhr, Guten Abend, gute Nacht, La Le Lu, Schlaf, Kindlein, schlaf Weißt Du, wie viel Sternelin stehen, Sandmann, Schlaf, mein Prinzchen, Der Mond ist aufgegangen, Wer hat die schönsten Schäfchen, Alles still, Abendstille, Fünf Pinguine, Ich bin ein Dicker Tanzbär, Fünf kleine Äffchen. Along with the above-mentioned songs, children and phonemes develop as spoken words $\beta, R, O ̈, \ddot{A}, \ddot{U}$ But listening to the songs in the Arabic language Baby TV that mimics the sounds of a child cannot develop the skill of Croatian characters. This may well disturb the development of a linguistic phase in a child. How to recognize speech-language communication difficulties: $\bullet$ Speech is not in accordance with the age of the child $\bullet$ Speech is more difficult to understand $\bullet$ the child has difficulty communicating with others $\bullet$ the child understands insufficiently the speech • the child does not hear well (communicating is more of a gesture). A full five-year-old child needs proper care articulate all the voices, and if there is any interference, you should seek expert advice logaoedics so that a child would not have difficulty getting to school (Pavičić, 2012).

Table 1. The Body Who Tolerates the Uncertain Representation after Thirty Years for the Void Glossary (Škaric, 1988)

\begin{tabular}{ccc}
\hline Voice & degree of damage & Years of child \\
\hline $\mathrm{S}$ & a distorted excuse & 4.5 \\
$\mathrm{Z}$ & “ & 4.5 \\
$\mathrm{C}$ & " & 4.5 \\
$\mathrm{R}$ & " & 5.5 \\
$\ddot{O}$ & " & 5.5 \\
$\mathrm{D} / \mathrm{T}$ & “ & 5.5 \\
$\ddot{\mathrm{A}}$ & replacement for 1 & 5.5 \\
$B$ & Replacement for n & 4 \\
$\ddot{U}$ & A distorted excuse & 3.5 \\
$\mathrm{R}$ & & 4 \\
\hline
\end{tabular}

The work starts with the affirmative hypothesis that just by watching a foreign Baby Tv with a foreign child, a child cannot fully develop Croatian letters. The beginning of the speech is fifteen months of the child's age. Girls usually talk faster than boys do. The third year the speech is shaped in rough moves and the child pronounces. Most votes and uses almost all kinds of words. The learned words are already connected in short sentences. By the end of the third year, a normally developed child distinguishes all the voices, he understands speaking and just talking. Then there is a perceptible difference between the understanding of others and their own speech activities. Usually, children speak easily, without the effort of themselves and close people. If so that is not the case, we enter into the area of various discrepancies in the development of speech and language. The course of development language and speech is a very powerful indicator of overall child development. The best method would be Electroencephalography, which is primarily a laboratory method of modern neurology, which provides insight into the functional state of the nervous system, particularly the brain and its parts. By carrying out the EEG(note 8) assay, a finding is called an electroencephalogram. He does consists of a series of curves showing changes in the electrical potential of individual points at skull surface caused by brain nerve cells. But the research was not used. 

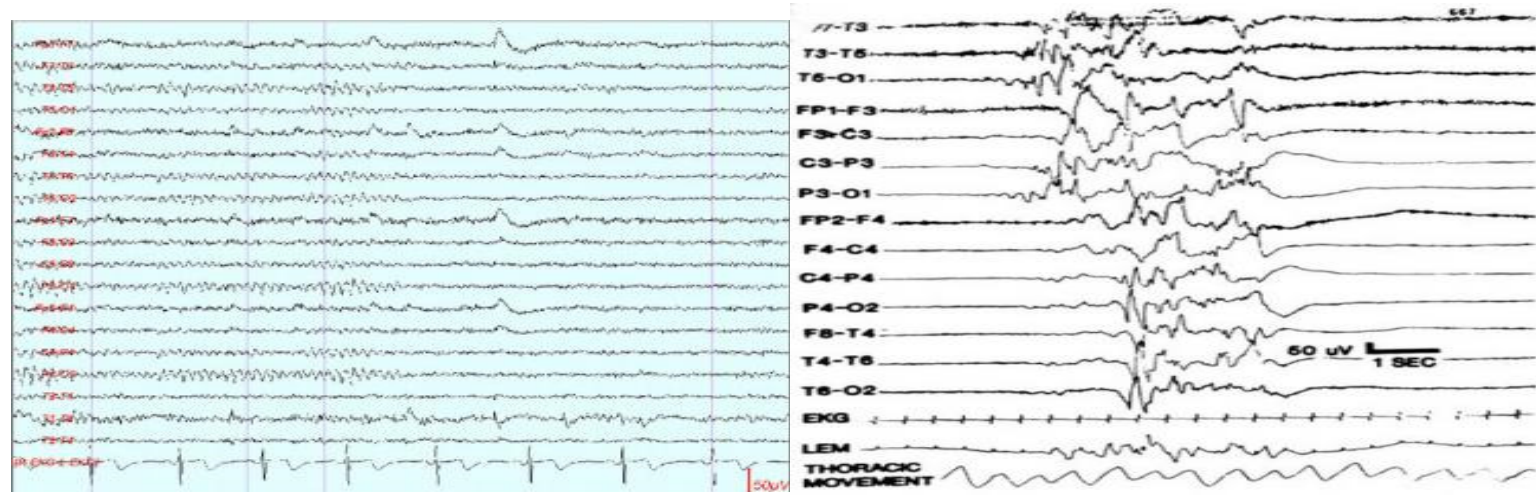

Picture 1. Normal EEG and Abnormal EEG

(Source note 9)

Speech development, it is important to note that there are great children among children individual differences. The child may say the first word with nine months, but also with two years, and later it can achieve neat speech-language development. Speech disorders can affect pronunciation, language, articulation, or to a voice (tone, height, volume or speed).

\section{Methods}

\subsection{The Aim of the Research}

BabyTV may unfortunately also have a negative impact on children's language-speaking development. If she is looking for a child too long, her language skills will be lower (preceptive skills will be weaker, sentences too simple, and the child will be stagnated in socializing with peers and parents). Little children do not differentiate between realities displayed on reality TV. When they see violence in cartoons or series, they often imitate him. Scenes of violence remember more easily than the whole story. Imitating such scenes, they can become unpopular with children (peers them are beginning to be avoided).

The aim of this research was to examine the negative influence of BABY TV on the speech of children with age child, sex, nonverbal, verbal abilities, and development scale of understanding speech.

\subsection{Hypothesis}

H1: Baby TV program in foreign language negatively affects children's linguistic-speech development. If they are looking for them for too long, their language skills will be lower, (the perceptive skills will be weaker, the sentences will be simpler, and the child will be bothered by socializing with peers and parents).

H0: There are no statistically significant differences in parents' opinion about the impact of some children's programs on Baby TV that work on children's linguistic development.

$\mathrm{H} 2$ : The frequency of using different types of children's songs from Baby TV program affects the child's speech development.

H0: There is no statistically significant difference in the opinion of the logoed about the impact of some children's programs on Baby TV that work on children's language-language development.

H0: There are no statistically significant differences in the sex of children about the impact of some children's songs on Baby TV that works on children's language-language development.

H3: Frequencies of watching German children's shows such as Deutsche Spieluhr, Guten Abend, Gute Nacht, La Le Lu, Schlaf, Kindlein, Schlaf Weißt Du, Wie viel Sternelin stehen, Sandmann, Schlaf, mein Prinzchen, Der Mond ist aufgegangen, Schönsten Schäfchen, Alles, and Abendstille, Fünf Pinguine, Ich bin ein Dicker Tanzbär, Fünf Kleine Äffchen, positively influence the development of child's speech in pronouncement: $\beta, R, \ddot{O}, \ddot{A}, \ddot{U}$.

H0: There are no statistically significant differences in the opinion of the logotherapists about the frequency of viewing German children's shows such as: Deutsche Spieluhr, Guten Abend, Gute Nacht, La Le Lu, Schlaf, Kindlein, Schlaf Weißt Du, Wie viel Sternelin stehen, Sandmann, Schlaf, Mein Prinzchen, Der Mond ist aufgegangen, Wer hat die schönsten Schäfchen, Alles, Abendstille, Fünf Pinguine, Ich bin ein Dicker Tanzbär, Fünf Kleine Äffchen, which 
positively influence the development of childrens speech at excuse: $\beta, R, O ̈, \ddot{A}, \ddot{U}$.

H0: There are no statistically significant reasons for children in the opinion of the logotherapists about the frequency of viewing German children's shows.

H4: More frequent viewing of foreign broadcasts Baby TV affects non-verbal intelligence of children.

H0: There is a statistically significant difference in non-verbal intelligence tests in children who are more likely to watch Baby TV than those who rarely watch.

\subsection{Research Method}

Of the 46 examined children, 33 were boys and 13 girls between the ages of 4 and 6 . The average age is 4.6 years old, the girl is 5.0 years old and the total average age of children is 5.2 years. The subjects in this study carried out the following diagnostic tests: pedagogical-psychological examination, logopedic examination, and neurological examination. Pedagogical-psychological examination evaluated psychomotor development and intellectual abilities patient. In this research, we are interested in our child's nonverbal abilities. During the test, psychomotor development psychologists are most often used by Wechsler's intelligence test for children who contains several separate subtests for verbal and nonverbal abilities. When evaluating speech linguistic and acoustic qualities were evaluated. Below the linguistic qualities, it implies Speech Development, Speech Richness, Speech Grammar, Speech Understanding, and Speech the patient's speech intelligibility. Acoustic qualities include voice quality, intonation, rhythm, tempo, and articulation. Reynell's speech development scale is intended to test speech abilities expressiveness and ability to understand speech (note 10). Neurological examination includes a standard neurological examination and statement. Includes evaluation developmental neurological age (development scale). The purpose of this test is to distinguish the organic from functional damage as a cause of speech difficulties.

\section{Results}

Of the 46 examined children, 33 were boys and 13 girls between the ages of 4 and 6 . The average age is 4.6 years old, the girl is 5.0 years old and the total average age of children is 5.2 years. The study was conducted at the Medizinisches Fakulät Mannheim (Germany) in the period from 29 January to 9 March 2018.

Based on the research we conducted, the most common speech disorders are articulation disorders, stigmatism, rotation, and stuttering. The researchers were discovered: articulation disorders, stigmatism, and rotation.

The articulation test consisted of:

1) Description of the picture

2) Logos and isolated voices - the logotherapists reads the logotomy, and the child repeats it; the voices that the child improperly speaks should be said to be isolated

3) of the voice sequence - words and logos - omissions, substitutions, additions, and metatars of voices and records resulting from the inability to memorize the voice sequence

Articulation disorders are deviations in the pronunciation of sounds or sound connections due to speech motor problems. From this, phonological disturbances are to be delimited, which lead to that sounds cannot be used at the correct position in the word. In articulation disorders, the sounding of one or more sounds does not conform to the so-called "standard pattern" of a language; i. a sound is not formed or wrong. Most often in German, the sibilants are affected. This articulatory abnormality is also referred to as "stigmatism" and occurs in various forms. 3.) Speaking Speech

4) Speech Test - The child describes the pictures

5) Voice word memory test using ten words and ten logos (for younger children four errors are allowed in words and five in logos, and in seven-year-old mistakes in one word and two logos).

The test objectivity was evaluated in 46 children. The correlation coefficient of the two testers is $0.95 \%$, which indicates a high degree of consistency, which was also demonstrated in the test of confidence by test-retest method on a sample of 46 children, where it was $0.96 \%$. 
Table 2. Test Reynolds Reynell's Developing Ladder of Speech Understanding

\begin{tabular}{|c|c|c|c|}
\hline Research & Results & Total/Nr. (\%) & Example \\
\hline $\begin{array}{l}\text { Reynell scale } \\
\text { understanding } \\
\text { speech }\end{array}$ & Neat & $7(15 \%)$ & 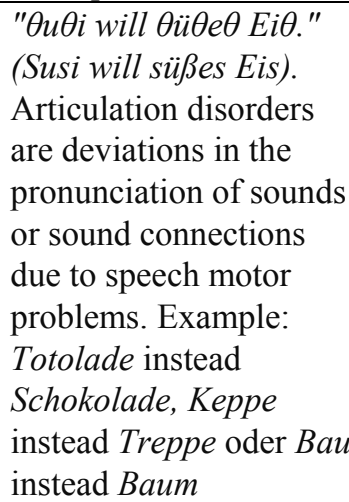 \\
\hline $\begin{array}{l}\text { Reynell scale } \\
\text { understanding } \\
\text { speech }\end{array}$ & Delay & $39(84 \%)$ & $\begin{array}{l}\text { "Schlon wieder ein zu } \\
\text { schlnelles Auto." } \\
\text { In addental education, } \\
\text { the tongue is not placed } \\
\text { between but too close to } \\
\text { the anterior teeth. In any } \\
\text { case, there is a changed } \\
\text { sound of the / s /, which } \\
\text { can be perceived as } \\
\text { "lisping". Also / sch / is } \\
\text { often articulately } \\
\text { changed in German. }\end{array}$ \\
\hline Total & & $46(100 \%)$ & \\
\hline
\end{tabular}

(Source: authors)

Table 2. shows the results that of the 46 respondents with language and speech development difficulties, only seven $15 \%$ (respondents were the result obtained by examining the Reynell Language Reading Scoreboard equals chronological age child. In 39 subjects, a significant delay was obtained in relation to the chronological age. The average delay is one year and five months. Five-year-olds often mispronounce one or two sound groups, for example, $\mathrm{t}$ and $\mathrm{d}$ or $\mathrm{s}, \mathrm{z}$, sch, and ch, or $\mathrm{f}$ and $\mathrm{w}$. The most common articulation disorder is the pronunciation of $s, z$, sch or $c h$. These are usually pronounced with the tongue between the teeth, and many children have problems using the tongue properly. The second most common error after the mistakes in making sibilants is the sounds $k$ and $g$ that many children replace with $t$ or $d$. However, they are no statistically significant differences in parents' opinion about the impact of some children's programs on Baby TV that work on children's linguistic development $\left(\chi^{2}=104.12, \mathrm{df}=5\right.$, $\mathrm{p} \leq .05$, Cramers $\mathrm{V}=.14$ ); and that there was no statistically significant difference of the opinion of the logotherapists about the impact of some children's programs on Baby TV that work on children's language-language development $\left(\chi^{2}=95.12, \mathrm{df}=3, \mathrm{p} \geq .05\right.$, Cramers $\left.\mathrm{V}=.12\right)$. Thus, Table 2 shows that even though 39 children had a diagnosed abnormal abilities language expression (F80.1), only seven have Reynell fit for age. 
Table 3. Statistics on the Type of Children's Songs Viewed on Baby TV and Comparison with German Children's Songs

\begin{tabular}{|c|c|c|c|c|c|c|}
\hline Research & $\begin{array}{c}\text { Baby } \\
\text { Tv-English } \\
\text { sounds }\end{array}$ & Total & $\begin{array}{c}\text { Results/Delay for English } \\
\text { songs }\end{array}$ & $\begin{array}{l}\text { Baby TV- } \\
\text { german } \\
\text { sounds }\end{array}$ & Total & $\begin{array}{c}\text { Results/ } \\
\text { Delay for German } \\
\text { songs }\end{array}$ \\
\hline $\begin{array}{l}\text { Reynell scale } \\
\text { understanding } \\
\text { speech }\end{array}$ & $\begin{array}{l}\text { Hokey } \\
\text { Pokey }\end{array}$ & $\begin{array}{c}5 \\
(10 \%)\end{array}$ & $\begin{array}{l}\text { Limited vocabulary: The } \\
\text { vocabulary of the child is } \\
\text { too small, i. it cannot name } \\
\text { many things according to } \\
\text { their age. It uses terms like } \\
\text { "that's there" and always } \\
\text { uses the same term } \\
\text { ("happa") for different } \\
\text { words (for example, } \\
\text { "biscuit", "bread" and } \\
\text { "spoon"). This disorder } \\
\text { usually never occurs on its } \\
\text { own, but often in } \\
\text { combination with dyslalia } \\
\text { and/or difficulty in } \\
\text { acquiring grammar. }\end{array}$ & $\begin{array}{l}\text { Benjamin } \\
\text { Blümchen }\end{array}$ & $4(8 \%)$ & $\begin{array}{l}\text { KV KR/GR, L, M: } \\
\text { Sigmatism } \\
\text { revealed as an } \\
\text { incorrect } \\
\text { pronunciation of } \\
\text { the } \mathrm{S}, \mathrm{Z}, \mathrm{C}\end{array}$ \\
\hline $\begin{array}{l}\text { Reynell scale } \\
\text { understanding } \\
\text { speech }\end{array}$ & $\begin{array}{l}\text { The finger } \\
\text { Family } \\
\text { songs }\end{array}$ & $\begin{array}{c}8 \\
(17 \%)\end{array}$ & $\begin{array}{l}\text { Lispeln (sigmatism): An } \\
\text { articulation disorder that } \\
\text { often occurs in children, in } \\
\text { which "S" sounds are } \\
\text { formed incorrectly (eg } \\
\text { tongue between the teeth). }\end{array}$ & $\begin{array}{l}\text { Schlaf, } \\
\text { Kindlein, } \\
\text { Schlaf } \\
\text { Sandmann, }\end{array}$ & $\begin{array}{c}10 \\
(21 \%)\end{array}$ & $\begin{array}{l}\text { KR/GR, L, M, N + } \\
\text { NG/NK: this blurs } \\
\text { with s and } \mathrm{z} \text { into an } \\
\text { exchange, sszsch, a } \\
\text { dschsch this blurs } \\
\text { with s and } \mathrm{z} \text { into an } \\
\text { exchange, sszsch, a } \\
\text { dschsch. } \\
\text { Articulation } \\
\text { disorders, } \\
\text { sigmatism, } \\
\text { rotation, and } \\
\text { stuttering. }\end{array}$ \\
\hline $\begin{array}{l}\text { Reynell scale } \\
\text { understanding } \\
\text { speech }\end{array}$ & $\begin{array}{l}\text { Twinkle } \\
\text { Twinkle } \\
\text { Little Star }\end{array}$ & $\begin{array}{c}10 \\
(21 \%)\end{array}$ & $\begin{array}{l}\text { Stuttering: Disturbing the } \\
\text { flow of speech through } \\
\text { repetitions of sounds, } \\
\text { syllables or words (eg } \\
\text { "kkk-kamen, } \\
\text { ge-ge-ge-heimnis") or by } \\
\text { hanging remain with } \\
\text { certain sounds, which is a } \\
\text { consequence of cramping } \\
\text { of the speech muscles } \\
\text { (silent press attempts } \\
\text { before / during the } \\
\text { speech). }\end{array}$ & $\begin{array}{l}\text { Weißt Du, } \\
\text { Wie viel } \\
\text { Sternelin } \\
\text { stehen, }\end{array}$ & $\begin{array}{c}21 \\
(45 \%)\end{array}$ & $\begin{array}{l}\mathrm{N}+\mathrm{NG} / \mathrm{NK}, \mathrm{P}, \mathrm{R}, \\
\mathrm{S}, \mathrm{SCH}, \mathrm{T}, \mathrm{KV} \\
\mathrm{TR} / \mathrm{DR}, \mathrm{W}, \ddot{\mathrm{A}}, \mathrm{O} \text {, } \\
\text { Ü: Ich tomm deich } \\
\text { (Ich komme } \\
\text { gleich.): Ich de son } \\
\text { in den tinderdaten. } \\
\text { (Ich gehe schon in } \\
\text { den Kindergarten.), } \\
\text { wimmbad } \\
\text { (Schwimmbad), } \\
\text { Dabel (Gabel), } \\
\text { Slange (Schlange): } \\
\text { Articulation } \\
\text { disorders, } \\
\text { sigmatism, rotation } \\
\text { and stuttering. }\end{array}$ \\
\hline $\begin{array}{l}\text { Reynell scale } \\
\text { understanding } \\
\text { speech }\end{array}$ & $\begin{array}{l}\mathrm{ABC} \\
\text { songs }\end{array}$ & $7(15 \%)$ & $\begin{array}{l}\text { Dysgrammatism: This } \\
\text { technical term describes } \\
\text { the inability to use the }\end{array}$ & Biene-Maja & $\begin{array}{c}6 \\
(13 \%)\end{array}$ & $\begin{array}{l}\text { Dyslalia } \\
\text { T, KV TR/DR } \\
\text { Limited }\end{array}$ \\
\hline
\end{tabular}




\begin{tabular}{|c|c|c|c|c|c|c|}
\hline & & & $\begin{array}{l}\text { language correctly } \\
\text { according to grammatical } \\
\text { rules (eg wrong sentence } \\
\text { structure, missing phrases } \\
\text {-> so-called telegram style, } \\
\text { inappropriate verb forms, } \\
\text { etc.). Dysgrammatism: } \\
\text { This technical term } \\
\text { describes the inability to } \\
\text { use the language correctly } \\
\text { according to grammatical } \\
\text { rules (eg wrong sentence } \\
\text { structure, missing phrases } \\
\text {-> so-called telegram style, } \\
\text { inappropriate verb forms, } \\
\text { etc.). Dysgrammatism: } \\
\text { This technical term } \\
\text { describes the inability to } \\
\text { use the language correctly } \\
\text { according to grammatical } \\
\text { rules (eg wrong sentence } \\
\text { structure, missing phrases } \\
\text {-> so-called telegram style, } \\
\text { inappropriate verb forms, } \\
\text { etc.). }\end{array}$ & & & $\begin{array}{l}\text { vocabulary: The } \\
\text { vocabulary of the } \\
\text { child is too small, i. } \\
\text { it cannot name } \\
\text { many things } \\
\text { according to their } \\
\text { age. It uses terms } \\
\text { like "that's there" } \\
\text { and always uses } \\
\text { the same term } \\
\text { ("happa") for } \\
\text { different words (for } \\
\text { example, "biscuit", } \\
\text { "bread" } \\
\text { "spoon"). This } \\
\text { disorder usually } \\
\text { never occurs on its } \\
\text { own, but often in } \\
\text { combination with } \\
\text { dyslalia and/or } \\
\text { difficulty in } \\
\text { acquiring grammar. }\end{array}$ \\
\hline $\begin{array}{l}\text { Reynell scale } \\
\text { understanding } \\
\text { speech }\end{array}$ & $\begin{array}{l}\text { Wheels On } \\
\text { The Bus }\end{array}$ & $11(23 \%)$ & $\begin{array}{l}\text { Dyslalia: Stammering } \\
\text { (disturbance of } \\
\text { pronunciation): Loud or } \\
\text { phonetic connections or } \\
\text { groups are omitted (flower } \\
=\text { lume) and/or replaced by } \\
\text { others (head = pot; } \\
\text { "Tindadaden" and/or } \\
\text { kindergarten) } \\
\text { formed wrong (rocking = } \\
\text { rocking) The sound } \\
\text { production does not } \\
\text { succeed according to the } \\
\text { age of the child. }\end{array}$ & $\begin{array}{l}\text { Alle Meine } \\
\text { Entchächen. }\end{array}$ & $\begin{array}{c}9 \\
(19 \%)\end{array}$ & $\begin{array}{l}\text { Dyslalia: } \\
\text { N + NG/NK, P, R, } \\
\text { S, SCH, T, KV } \\
\text { TR/DR, W, Ä, Ö, } \\
\text { Ü), }\end{array}$ \\
\hline $\begin{array}{l}\text { Reynell scale } \\
\text { understanding } \\
\text { speech }\end{array}$ & $\frac{\text { Five little }}{\text { penguins }}$ & $2(4 \%)$ & $\begin{array}{l}\text { It uses terms like "that's } \\
\text { there" and always uses the } \\
\text { same term ("happa") for } \\
\text { different words (for } \\
\text { example, "biscuit", "bread" } \\
\text { and "spoon") }\end{array}$ & $\begin{array}{l}\text { Fünf } \\
\text { Pinguine, }\end{array}$ & $\begin{array}{c}13 \\
(28 \%)\end{array}$ & $\begin{array}{l}\text { Rotation } \\
\text { stuttering.P, R, S, } \\
\text { SCH, T, KV } \\
\text { TR/DR, W, Ä, Ö, } \\
\text { Ü }\end{array}$ \\
\hline \multirow[t]{2}{*}{$\begin{array}{l}\text { Reynell scale } \\
\text { understanding } \\
\text { speech }\end{array}$} & $\begin{array}{l}\text { Itsy Bitsy } \\
\text { Spider }\end{array}$ & $3(6 \%)$ & Lispeln (Sigmatism) & $\begin{array}{l}\text { Ich bin ein } \\
\text { Dicker } \\
\text { Tanzbär }\end{array}$ & $\begin{array}{c}7 \\
(12 \%)\end{array}$ & $\begin{array}{l}\text { Rotation and } \\
\text { stuttering.B, D, F, } \\
\text { G, CH1, CH2, K, } \\
\text { KV KR/GR, L, M }\end{array}$ \\
\hline & & $\begin{array}{l}\text { Total } 46 \\
(100 \%)\end{array}$ & & & $\begin{array}{c}\text { Total: } \\
46 \\
(100 \%)\end{array}$ & \\
\hline
\end{tabular}

(Source: authors) 
Table 3. shows the results that of the 46 respondents with language and speech development difficulties, it shows the Statistics on the type of children's songs viewed on Baby TV and comparison with German children's songs, the Reynell scale understanding speech, the tracks the children most frequently watched on the Baby TV program caused the following linguistic-speech disorders: English songs: Twinkle Twinkle Little Star (10, 21\%); Wheels On The Bus (11, 23\%); germans songs: Weißt Du, Wie viel Sternelin stehen (21, 45\%) and the songs Schlaf, Kindlein, Schlaf Sandmann (10, 21\%). However, there are no statistically significant differences in the sex of children about the impact of some children's songs on Baby TV that works on children's language-language development. $\left(\chi^{2}=116.13\right.$, $\mathrm{df}=4, \mathrm{p} \leq .05$, Cramers $\mathrm{V}=.18$ ); and that there are no statistically significant differences in the opinion of the logotherapists about the frequency of viewing German children's shows such as: Deutsche Spieluhr, Guten Abend, Gute Nacht, La Le Lu, Schlaf, Kindlein, Schlaf Weißt Du, Wie viel Sternelin stehen, Sandmann, Schlaf, Mein Prinzchen, Der Mond ist aufgegangen, Wer hat die schönsten Schäfchen, Alles, Abendstille, Fünf Pinguine, Ich bin ein Dicker Tanzbär, Fünf Kleine Äffchen, which positively influence the development of children's speech at excuse: $\beta, R, \ddot{O}, \ddot{A}, \ddot{U}\left(\chi^{2}=98.21, d f=6, p \geq .05\right.$, Cramers $\left.V=.17\right)$; they there no statistically significant reasons for children in the opinion of the logotherapists about the frequency of viewing German children's shows $\ddot{U}\left(\chi^{2}=111.41\right.$, $\mathrm{df}=2$, $\mathrm{p} \geq .05$, Cramers $\mathrm{V}=.19$ ). When compared to nonverbal and verbal abilities in this study, 46 of the respondents were determined by regular or average nonverbal abilities, with $31(67 \%)$ delay in either lagging in nonverbal abilities. By studying verbal skills, it is noticed that 24 of them have average verbal abilities and $22(47 \%)$ of them have a lag. This is concluded how respondents have better nonverbal ability than verbal. The ability to speak and understand speech in relation to Reynell was also explored development scale of speech. Average and below-average values were obtained. The results also show that there is a statistically significant difference in non-verbal intelligence tests in children who are more likely to watch Baby TV than those who rarely watch $\left(\chi^{2}=104.11, \mathrm{df}=3, \mathrm{p} \leq .05\right.$, Cramers $\mathrm{V}=.21$ ). A statistically significant correlation (Kendallov Tau $=-0,413$ ) was obtained, although parents who sing along with their children of poetry and teach them how to pronounce German swirling together, research has shown that these children have less difficulty in pronouncing more difficult words and merging sentences.

Table 4. Review of Satisfaction Correlation Parents Who Sing Along With Their Children of Poetry and Teach Them How to Pronounce German Swirling Together, Research Has Shown That These Children Have Less Difficulty in Pronouncing Words That Are More Difficult and Merging Sentences

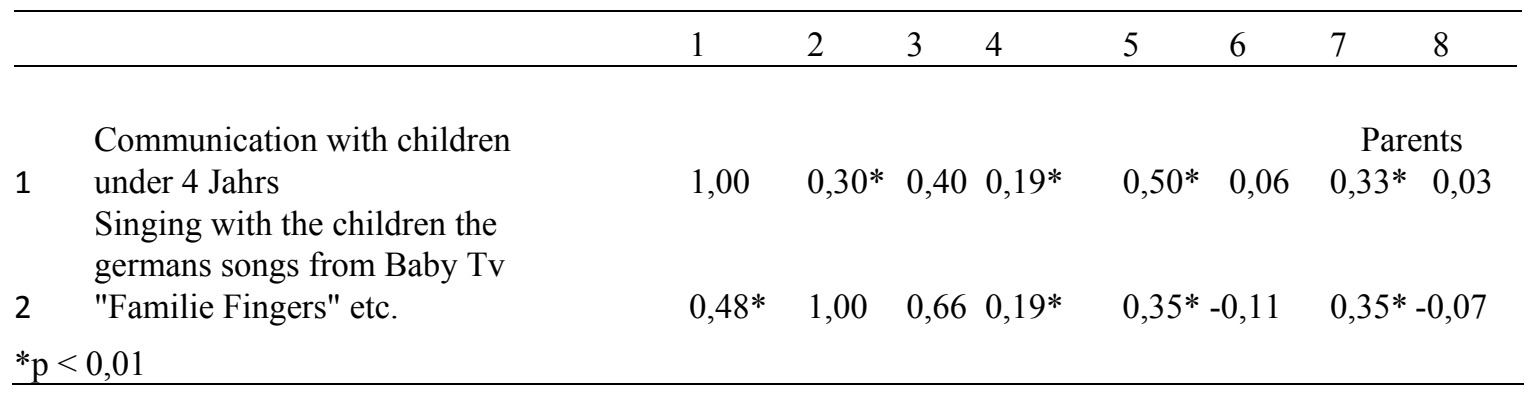

(Source: authors)

Correlations showed that there is a link between although parents who sing along with their children of poetry and teach them how to pronounce German swirling together, research has shown that these children have less difficulty in pronouncing more difficult words and merging sentences. $(\mathrm{r}=0,66, \mathrm{p} \leq .05)$. While there is no significant correlation among boys, among girls the correlation is clear $(\mathrm{r}=0.35, \mathrm{p} \leq .05)$ (note 11$)$.

\section{Discussion}

Here, the developing brain takes an active role. It seeks out the information and stimuli it needs as "feed" for these processes. Everything else fades it out. This also explains why children are interested in other things than adults. They pay attention to what is important according to their development. Therefore, the newscast rushes past them during the last general election, while the fish in the aquarium or the grandma, who tells a fairy tale, receive full attention. The central principle here is that brain development always builds on what already exists and that a third step cannot be taken before the second one. This can be nicely ignored by language development. In the one-word phase, the child learns that the things of the world can be addressed and described with sound sequences. For example, "Ball" stands for that round thing with which you can play so beautifully. This is followed by the two-word phase and the multi-word phase, each of which presupposes the preceding learning steps. Accordingly, the areas that 
are important in the brain for these language skills are differentiated.

Table 5. The Phase of Language Development

\begin{tabular}{|c|c|c|c|}
\hline $\begin{array}{l}\text { Phases of language } \\
\text { development }\end{array}$ & & & \\
\hline first word phases & second phase host & More word phase & Multi-word phrases \\
\hline $\begin{array}{l}\text { Individual words stand for a } \\
\text { complex relationship, e.g. } \\
\text { "Construction" (I want to } \\
\text { play ball, or Where is the } \\
\text { ball?) }\end{array}$ & $\begin{array}{l}\text { Telegram style of two } \\
\text { words, mostly noun and } \\
\text { verb in the infinitive, eg } \\
\text { "Ba ham" (I want to have } \\
\text { the ball) }\end{array}$ & $\begin{array}{l}\text { Three or more words, } \\
\text { mostly noun, the verb in } \\
\text { the infinitive and } \\
\text { adjective, eg "Mama, } \\
\text { tommnell" (Mama, } \\
\text { come quickly!). } \\
\text { Development of your } \\
\text { own grammatical } \\
\text { blueprint; Variations of } \\
\text { statements, questions, } \\
\text { exclamations }\end{array}$ & $\begin{array}{l}\text { Differentiated } \\
\text { sentences with } \\
\text { subordinate sentence } \\
\text { constructions; } \\
\text { improved } \\
\text { pronunciation; } \\
\text { Mastering difficult } \\
\text { sounds and } \\
\text { combinations of } \\
\text { sounds like "sch" or } \\
\text { "kn"; strong increase } \\
\text { in vocabulary }\end{array}$ \\
\hline
\end{tabular}

(Source: Kramer, 2002).

For language acquisition, it is very important that children actively speak. Only in this way can the necessary neural networks emerge. Children or their brains depend on language input for language acquisition. However, it is also important for them to become active themselves, to shape their communication themselves in order to get the linguistic stimuli and suggestions they need in the particular phase of their language development. In addition, a connection with emotions is helpful because the neurobiological processes of learning are influenced by emotions. We learn better, when the acquisition of new knowledge networks is connected with feelings. This is an exciting insight into modern brain research. A positive emotional relationship with the child and an encouraging style of parenting are essential for learning and language acquisition. Ten best ways to promote the child linguistically the ten best ways to promote the child linguistically: 1. Audition and sing together (Even babies and toddlers react extremely positively to music by smiling and moving. When parents sing something to their children, they listen intently to the sound of their voice. The audition and the later singing together teach children the rhythm and melody of their mother tongue (s) but above all the fun of the language - an important prerequisite for language development); 2. Finger games, Kniereiter, and rhymes (This is the thumb that shakes the plums ... - many parents will know this familiar finger game from their own childhood. Unconsciously, generations of parents linguistically encouraged their children with fingering, kneading, and rhyming. The z.T. Very old language games are still incredibly popular with babies and toddlers and strengthen the emotional bond between parent and child. Toddlers get used to the rhythm and sounds of the language.) 3. Watch picture books together (From about half a year you can start with your child to look at simple picture books. Particularly popular with very small readers are so-called feeling books to touch. For starters, picture books with one picture per page are suitable. They help children to understand the symbol level - an important prerequisite for reading later on. From about one and a half years on the popularity of small children's Wimmel books on large-scale images, there is always something new to discover and to name. The colorful and detailed illustrations offer numerous language options. When the pictures are viewed together, children playfully expand and consolidate their vocabulary). 4. Read aloud (Reading aloud is one of the most important ways to promote children's language. Unfortunately, it is too short in many families today. In addition to language development, reading aloud promotes concentration as well as imagination and creativity. Therefore, take time to read aloud regularly. Have your child choose a book for themselves and make yourself comfortable reading. Reading recommendations for children and adolescents can be found at the "Stiftung Lesen"). 5. Talk a lot to the child (Children learn a language through imitation, among other things. If they grow up in a low-communication environment, they will remain linguistically on the track. That is why you should talk a lot with your baby and toddler right from the start. The address is not just a form of affection but also helps children to get a feel for their mother tongue. You will get to know the speech melody and distinguish different voices), 6. Accompany your own actions linguistically (Accompany your own actions linguistically, even if monologizing seems to take some getting used to at the beginning. Explain to your child what you are doing and involve yourself in your activities as far as possible. Your child will listen to you carefully and soon establish a connection between your actions and your words). 7. Play together (When playing, children discover the 
world - and the language. Therefore, offer your child a variety of game suggestions. However, they do not have to be special language training games. Particularly popular with toddlers are role-playing games such as mother and child, shop or doctor. When adapting to everyday situations, children develop their vocabulary and consolidate grammatical structures. From 3 to 4 years you can play with your child also simple board games like Memory or Domino. In these games, children name many different items and expand their vocabulary)., 8. Correct - the improved repetition (corrective feedback). No child speaks perfect from the beginning. Proper pronunciation and grammatically correct formation of words and sentences must be practiced. Always correct your child by repeating the linguistically correct wording casually. Never make fun of a phrase or tease your child with his mistakes. This unsettles children and deprives them of the pleasure and joy of speaking). 9. Use baby language only in moderation (Wau wau, brumm hum, Kikeriki - the onomatopoeia of objects and actions is used by many parents, especially in the first two years of life. But simplification is not always conducive to your child's language development. Try to name items, people, and actions by their real name as early as possible). 10. Give the child the opportunity to speak. Practice makes perfect - that is also true for speaking. The more opportunity your child has to express themselves in language, the better and safer it will be in terms of language. The most commonly used poems for children with a speech disorder that are used as a rehabilitation method in a Mannheim hospital are: All birds are already there; the May has come; A man who called himself Columbus; A bird wanted to make a wedding; It rattles the mill at the rushing brook; Hejo! Tighten the car!; In the Märzen the farmer; The woods are already colorful; Taler, Taler, you have to hike; Now we drive over the lake; Not a beautiful country and Cuckoo, cuckoo (call it from the forest.(Note 12))

Today in Germany there are so-called "Kinder Apps Sprchen and Sprachen lernen", which provides children and parents with the help of smart apps, gadgets and educational programs on Tablets (even if children are surrounded by them) with children's swords and exercises to learn to properly pronounce certain phonemes, words and wholesome sentences in German. Some of them are known: Eli Explorer - 1. "Sprach-Lernspiel App für kleine Kinder" (iPad, iPhone); 2. "Monsters behave! - Sprachspiel App mit lustigen Monstern für Kinder ab 4 Jahre"; 3. "Dein illustriertes Wörterbuch - Kinder App zum Fremdsprachen Kennenlernen"; and 4. "Happi Wörter - Eine Wort Assoziationsspiel App für Kinder, iPad iPhone..."

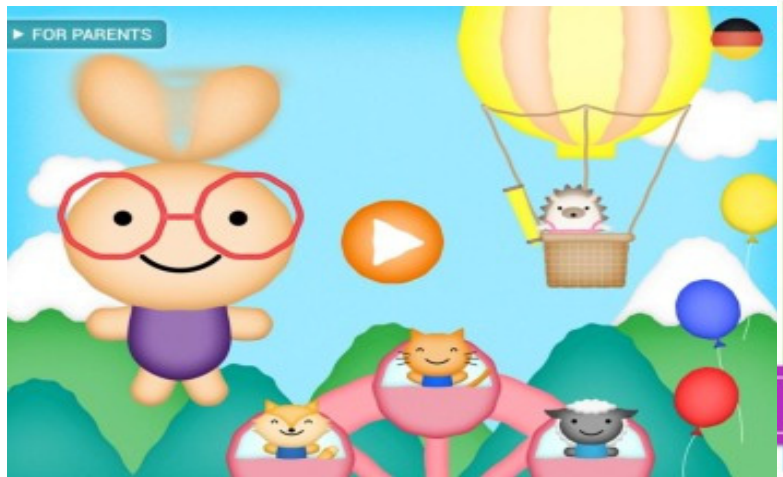

1. Language Educational Game

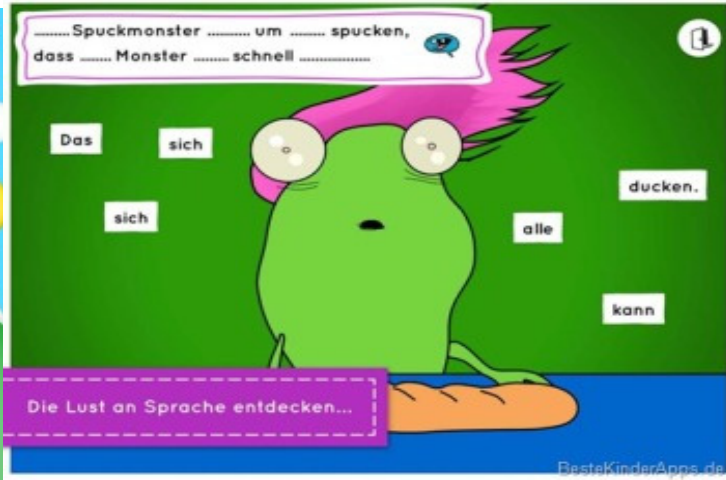

2. Monsters Behave

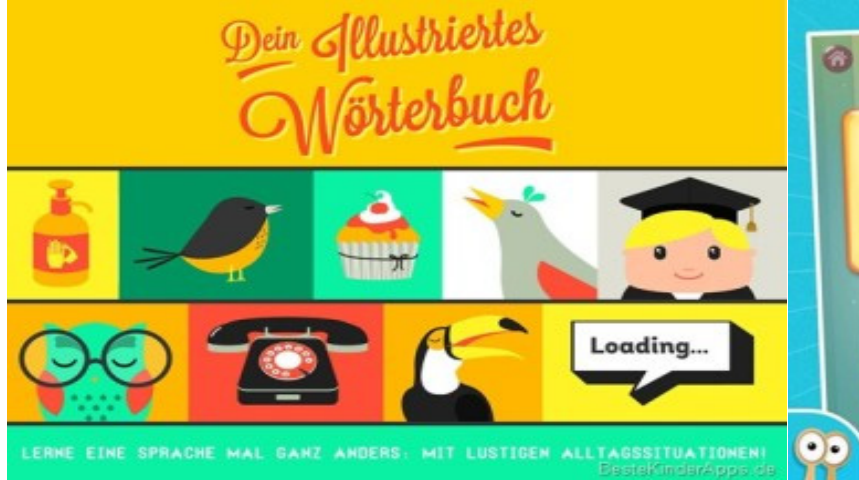

3. Your Illustrated Dictionary

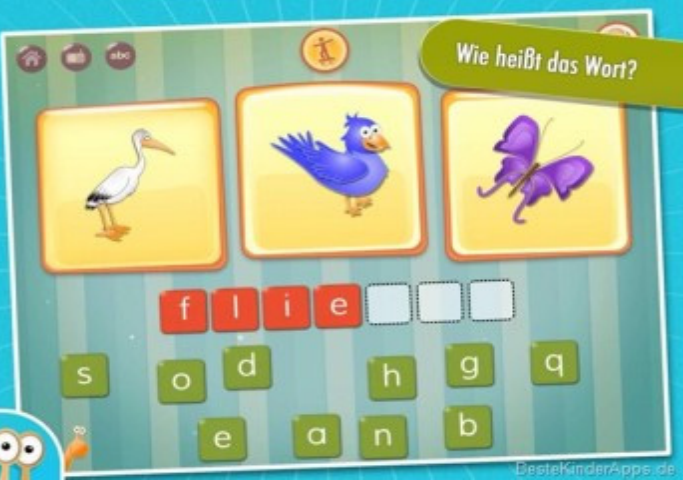

4. Happy Words

Picture 1. Smart Apps to Correctly Pronounce German Phonemes, Letters, Words, Sentences

Source: http://bestekinderapps.de/sprechen-sprachen-lernen-apps 


\section{Conclusion}

For this reason, there is a very important correlation between conclusions for elementary pedagogy, psychology, neurology, communology and logotherapists for a better explanation of the influence of children's Baby Tv on language development speech in children as well as in deciding on rehabilitation and prevention. The research has identified the following hypotheses of work: H1: Baby TV program in foreign language negatively affects children's linguistic-speech development. If they are looking for them for too long, their language skills will be lower (the preceptive skills will be weaker, the sentences will be simpler, and the child will be bothered by socializing with peers and parents); H2: The frequency of using different types of children's songs from Baby TV program affects the child's speech development.; H3: Frequencies of watching German children's shows such as Deutsche Spieluhr, Guten Abend, Gute Nacht, La Le Lu, Schlaf, Kindlein, Schlaf Weißt Du, Wie viel Sternelin stehen, Sandmann, Schlaf, mein Prinzchen, Der Mond ist aufgegangen, Schönsten Schäfchen, Alles, and Abendstille, Fünf Pinguine, Ich bin ein Dicker Tanzbär, Fünf Kleine Äffchen, positively influence the development of child's speech in pronouncement: $B, \mathrm{R}$, $\ddot{\mathrm{O}}, \ddot{\mathrm{A}}, \ddot{\mathrm{U}}$; and accepted the thesis of the work H4: More frequent viewing of foreign broadcasts Baby TV affects non-verbal intelligence of children. The results research shows that besides the worse results on non-verbal intelligence tests, children who were exposed to the influence of Baby-TV from their 2 to 4-year-olds have achieved worse results on nonverbal tests as well as children whose parents included the Baby-TV program of 9 months to the gosling of the day. They say the worst German letters such as $\beta, R, O ̈, \ddot{A}, \ddot{U}$ and do not associate German spoken words with the environment. If children speak badly, it can have several causes. Much television, as often assumed, is not alone responsible. Nevertheless, excessive TV consumption can aggravate the symptoms. Stead, it is important that especially the parents talk with their children. As often and as much as possible. Read books, sing children's songs, nursery rhymes - anything that promotes the children's speaking in a playful way, should necessarily and necessarily belong to every family life. And if it is supposed to be a movie, it can also be used as an opportunity to talk to the children about what they have seen. This is more time-consuming and time-consuming than putting the children off the screen. This is maybe an example for Croatia, but the necessary correlations between the logs, psychologists, and neurologists are needed if the EEG, parents and related experts as communicators.

\section{References}

Adomeit, K. (1997). Hochschulreform und was nun?- Berichte- Glossen Perspektiven. Ullstein Buch: Berlin.

Ashauer, G. (2004). Handbuch des audio-visuellen Lehrens und Lernens. Deutscher Sparkassenverlag: Stuttgart.

Comrie, B., Matthews, S., \& Polinsky, M. (2003). Atlas jezika. Varaždin: Stanek d.o.o.

Dohmen, G. (2001). Informelles Lernen - Die internationale Erschließung einer bisher vernachlässigten Grundform menschlichen Lernens für das lebenslange. Lernen aller, BMBF: Bonn.

Farke, G. (2006). OnlineSucht - Wenn Mailen und Chatten zum Zwang werde. Sttutgart: Kreuz Verlag GmbH und Co. KG.

Gerhard, F., \& Streit. (2002). Was sich im Kopf abspielt. Erkenntnisse aus der Hirnforschung und ihre Bedeutung für die Elementarpädagogik. Kindergarten heute, Jahrgang, 32, 6-11.

Kolonko, B. (2002). Sprechenlernen ist eine erstaunliche Leistung. Kinder auf dem Weg zur Sprache. In: TPS Evangelische Zeitschrift für die Arbeit mit Kindern, Theorie und Praxis der Sozialpädagogik - Sammelband Kinder - Lernen - Bildung, Seelze/Velbert 2002, S. 25-27.

Kramer, K. (2003). Wie werde ich ein Sprachgenie? In: Gehirn und Geist, Spektrum, Akademischer Verlag, Heidelberg 2/2003, S. 48-50.

Militzer, Renate (Hg). (2001). Wer spricht mit mir? Gezielte Sprachförderung für Kinder mit Migrationshintergrund, Ministerium für Frauen, Jugend, Familie und Gesundheit des Landes. Nordrhein-Westfalen: Düsseldorf Dezember.

Militzer, Renate (Hg). (2001). Wie Kinder sprechen lernen. Entwicklung und Förderung der Sprache im Elementarbereich, Ministerium für Frauen, Jugend, Familie und Gesundheit des Landes. Nordrhein-Westfalen: Düsseldorf März.

Pavličević-Franić, D. (2005). Komunikacijom do gramatike. Razvoj komunikacijske kompetencije u ranome razdoblju usvajanja jezika. Zagreb: Alfa.

Silberg, J. (2006). Igre mozgalice. Zagreb: Profil international. 
Singer, W. (1998). "Früh übt sich..." Zur Neurobiologie des Lernens. In: Mantel, Gerhard (Hg.), Ungenutzte Potentiale: Wege zu konstruktivem Üben. Schott, Mainz, S. 43-53.

Singer, W. (2002). Was kann ein Mensch wann lernen? Ergebnisse aus der Hirnforschung. In: TPS - Evangelische Zeitschrift für die Arbeit mit Kindern, Theorie und Praxis der Sozialpädagogik - Sammelband Kinder - Lernen Bildung, Seelze/Velbert, S. 4-9.

Škarić I. (1988). Govorne poteškoće i njihovo uklanjanje. Zagreb: Mladost.

Stančić, V., \& Ljubešić, M. (1994). Jezik, govor, spoznaja. Zagreb: Hrvatska sveučilišna naklada.

Youngblood, N. M., \& Hines J. (1992.). The influence of the family s perception on disability on rehabilitation outcomes. U: Reinhardt, J.P., D Allura, T. Social support and adjustment to vision impairment across the life span. U: Silverstone B. Et al. The Lighthouse handbook on vision impairment and vision rehabilitation. Oxford university press: New York.

\section{Notes}

Note 1.

http://www.t-online.de/gesundheit/kindergesundheit/id_79843886/sprachstoerungen-bei-kindern-nehmen-zu.html

Note 2. Ebenda 1

Note 3. Ebenda 2

Note 4. http://www.dailymail.co.uk/news/article-1077332/Are-children-risk-baby-TV-stations.html\#ixzz58t9refIC

Note 5. Ibid.

Note 6. (Singer,2008.)

Note 7. Kramer, K. (2003): Wie werde ich ein Sprachgenie? In: Gehirn und Geist, Spektrum Akademischer Verlag, Heidelberg 2/2003, S. 48-50. and Militzer, Renate (Hg.) (2001): Wer spricht mit mir? Gezielte Sprachförderung für Kinder mit Migrationshintergrund, Ministerium für Frauen, Jugend, Familie und Gesundheit des Landes Nordrhein-Westfalen, Düsseldorf Dezember.

Note 8. Electroencephalography (EEG) is an electrophysiological monitoring method to record the electrical activity of the brain. It is typically noninvasive, with the electrodes placed along the scalp, although invasive electrodes are sometimes used such as in electrocorticography. EEG measures voltage fluctuations resulting from ionic current within the neurons of the brain.

Note 9.

https://www.google.hr/search? $\mathrm{q}=$ electroencefalograma + anormal\&sa $=X \& d c r=0 \& t b m=i s c h \& t b o=u \&$ source $=$ univ\&ve $\mathrm{d}=0$ ahUKEwjDxZklOLZAhWFJ5oKHXACAu4QsAQIKA\&biw=1600\&bih=805

Note 10. In this study, children with developmental and language difficulties were examined speech. The examination consists of three ladders: Speech A, Ladders for understanding speech B and speech expression scale.

Note 11. In 2011, 648,000 of the legally insured children between the ages of five and 14 had a speech disorder. In 2015 , there were 715,000 children - that is an increase of more than ten percent, as an extrapolation of the health insurance Barmer GEK shows. Besides medical causes are also social factors with the fault on the rise. According to pediatricians, a major problem is increasing media consumption: children watch monitors too much silently and speak too little. But speaking is mainly learned by practicing it.

Note 12. Orig. Alle Vöglein sind schon da; Der Mai ist gekommen; Ein Mann der sich Kolumbus nannte; Ein Vogel wollte Hochzeit machen; Es klappert die Mühle am rauschenden Bach; Hejo! Spann den Wagen an!; Im Märzen der Bauer; Bunt sind schon die Wälder; Taler, Taler, du musst wandern; Jetzt fahrn wir über'n See; Kein schöner Land; Kuckuck, kuckuck (ruft's aus dem Wald) 